\title{
The effects of seasonal variation on the nutritional condition of Nephrops norvegicus (Astacidea: Nephropidae) from wild populations in the western Mediterranean
}

\author{
GUIOMAR ROTLLANT ${ }^{1,2}$, JOAN B. COMPANY ${ }^{1}$, INMACULADA ALVAREZ-FERNÁNDEZ ${ }^{3}$, JOSÉ A. GARCÍA ${ }^{1}$, \\ JACOPO AGUZZI ${ }^{1}$ AND MERCÈ DURFORT ${ }^{4}$ \\ ${ }^{1}$ Institut de Ciències del Mar, Consejo Superior de Investigaciones Científicas (ICM-CSIC), Passeig Marítim de la Barceloneta 36-49, \\ 08003 Barcelona, Spain, ${ }^{2}$ IRTA, Ctra. Poble Nou, Km. 5.5, 43540. Sant Carles de la Ràpita (Tarragona), Spain, ${ }^{3}$ Grupo de Recursos \\ Marinos y Pesquerías, Universidad de A Coruña, Rúa da Fraga 10, 15008 A Coruña, Spain, ${ }^{4}$ Departament de Biologia Cel-lular, \\ Facultad de Biologia, Universitat de Barcelona, Avenida Diagonal, 643, 08028 Barcelona, Spain
}

\begin{abstract}
The Norway lobster, Nephrops norvegicus is a target fishery species in European waters. The stock assessment of N. norvegicus is complicated because it is caught in commercial gear only when it emerges from its burrow. Landings are lower in winter, and feeding limitations have been hypothesized as the cause. Wild large-sized male lobsters were sampled each season (winter, spring, summer and autumn), and two groups of animals were kept in captivity for $90 \mathrm{~d}$ (fed and fooddeprived). The hepatopancreas and muscle were dissected, weighted, frozen for biochemical analyses (proximal analyses and DNA/RNA) and fixed in Bouin solution for microscopic observations. The oxygen consumption rates in the wild individuals caught in the spring and in the captive animals after the treatments were measured. Significant differences among the experimental groups were observed in the lipid concentration of the hepatopancreas and muscle, the water content in the hepatopancreas, and the numbers of vacuoles and pyknotic nuclei in the cells of the tubules of the hepatopancreas. The results showed that the wild Norway lobsters generally presented intermediate values between those observed in the fooddeprived and the fed lobsters kept in captivity, but the values were closer to those obtained for the fed animals. This finding indicates that the wild animals exhibit a good nutritional condition throughout the year. Therefore, the wild males of $\mathrm{N}$. norvegicus do not face food deprivation during winter as is suggested by the pattern of commercial catches, the flow of organic matter, and the moulting period/reproductive behaviour of the species.
\end{abstract}

Keywords: Nephrops, feeding, food deprivation, annual cycle, nutritional condition indices, biochemical composition, tissue morphology, RNA/DNA, oxygen consumption, fisheries management

Submitted 25 March 2013; accepted 5 January 2014; first published online 14 February 2014

\section{INTRDDUCTION}

The Norway lobster Nephrops norvegicus (L. 1758) is a resource of high commercial value for the north-east Atlantic Ocean and Mediterranean fisheries (Sardà, 1998a; Bell et al., 2006). On the Catalan coast (western Mediterranean), $N$. norvegicus landings attain approximately $200 \mathrm{t} \mathrm{yr}^{-1}$, with a current value of $€ 3.5 \mathrm{~m}$ and an average price at the first sale ashore of approximately $€_{30} \mathrm{~kg}^{-1}$ (database of the Catalan Autonomous Government). In this region, the populations that are located on the upper and slope layers (at a depth of approximately $400 \mathrm{~m}$ ) (Abelló et al., 1988, 2002a, b; Cartes \& Sarda, 1993; Maynou \& Sardà, 1997; Maynou et al., 1998) are exposed to heavy fishing pressure (Sardà \& Lleonart, 1993; Maynou et al., 1998) and show signs of over-

Corresponding author:

G. Rotllant

Email: guio@icm.csic.es exploitation (Sardà, 1998b). In addition, a decrease in the size at first maturity has been suggested (Rotllant et al., 2005).

Nephrops inhabit burrows and perform short excursions to feed by predation and scavenging (reviewed by Aguzzi \& Sardà, 2008). Synchronous emergence into the population induces marked diel fluctuations in catchability (Aguzzi et al., 2003b). In fact, animals can be caught by towed trawl nets only when residing outside of their burrows (Main \& Sangster, 1985). Burrow emergence behaviour is related to the light intensity cycle, which acts directly on the animal's biological clock (Chiesa et al., 2010). Such light-driven behavioural entrainment has adaptive value, because Nephrops relies on an optimum light intensity level to perform its burrow emergence and retrieve its food, which can also be identified with the help of food odours (Aguzzi \& Sardà, 2008). Accordingly, western Mediterranean populations show a massive emergence from the crepuscular to the full midday hours in areas between 80 and $400 \mathrm{~m}$ depth (Aguzzi et al., 2003 b).

Nephrops norvegicus catchability also varies at a seasonal scale, and landings are greater in late spring and early summer (Farmer, 1975; Sardà, 1998a). The length of the 
photoperiod directly modulates the duration of emergence (Aguzzi et al., 2004) because this action is most likely synergistic with seasonal modifications in food inputs. Although these food inputs have been poorly investigated, the seasonal fluctuation in primary production changes the amount of sinking organic matter (Heussner et al., 2006). In the western Mediterranean, this shift results in a lower diversity of epibenthic prey in the autumn and winter (Cristo \& Cartes, 1998). This phenomenon may be of importance because Nephrops are territorial and feed on items that are readily available near the burrows (Farmer, 1975). The synchronization of the Nephrops reproductive cycle may also occur based on seasonal variation in organic matter input, as typically observed in deep-sea species (Company et al., 2008).

Previous laboratory studies on the effects of starvation on Nephrops have noted the occurrence of biomass (wet and dry weight and ash content), biometric (primarily carapace length and width), biochemical (elemental, proximal and fatty acid composition, RNA:DNA ratio), and metabolic changes (oxygen consumption), which were quantified as conditional nutrition indices (Dall, 1981; Sardà \& Valladares, 1990; Baden et al., 1994; Parslow-Williams, 1998; ParslowWilliams et al., 2001, 2002; Rotllant et al., 2004; Mente, 2010; Mente et al., 2011; Watts, 2012). Several of these indices have been used to determine the vital state in Nephrops according to different feeding treatments (Rotllant et al., 2001; Mente, 2010), growth capacities (Tuck et al., 1997), or sex (Rosa \& Nunes, 2002).

To determine whether the variation in seasonal catchability in Nephrops is related to modifications in the fluxes of input organic matter (producing a decrease in overall food availability), we evaluated the nutritional condition of freshly caught individuals, which were sampled seasonally, through biochemical and metabolic indices and compared them with individuals that were maintained in the laboratory for $90 \mathrm{~d}$ under fed and food-deprived conditions as a control.

\section{MATERIALS AND METHODS}

\section{Animal sampling and tissue collection}

Large-sized adults (carapace length, $\mathrm{CL}=34.2 \pm 4.2 \mathrm{~mm}$ ) were freshly collected by commercial trawlers from depths of $\sim 400-450 \mathrm{~m}$ off Barcelona. Commercial trawlers in the area, such as those used in the present study ('Maireta III', 'Zorrilla' and 'Francesc i Lluis'), usually perform two hauls per day, one starting at sunrise and the other at midday (Sardà, 1998a). The animals tested in the present study were collected from the second haul. The animals were maintained in $30 \mathrm{~L}$ dark transport tanks filled with seawater collected in the area of trawling and cooled with seawater ice packs to $12 \pm 2{ }^{\circ} \mathrm{C}$. A few hours after their capture, the lobsters arrived at the laboratory. The wild animals were maintained in their transport tanks for one hour after arriving at the laboratory to minimize the stress associated with transport. Only individuals in the intermoult stage (C) (Sardà, 1983) with the first two pereiopods and no apparent external injuries were used for the condition analysis $(\mathrm{N}=10$ freshly caught individuals for each season, $\mathrm{N}=30$ for the fed treatment and $\mathrm{N}=60$ for the food-deprived treatment). The lobsters were sampled each season (winter (Win), spring (Spr), summer (Sum) and autumn (Aut)); and in winter for the two laboratory captivity treatments (fed (F) and fooddeprived (FD)).

The whole hepatopancreas and the muscle from the tail (without epidermis) were dissected. A portion from each tissue was frozen at $-80^{\circ} \mathrm{C}$ for biochemical analyses (see below), and another was fixed in Bouin solution for microscopic observations. For nucleic acid analyses, samples were lyophilized before shipping to the Marine Biological Station of Helgoland (Alfred Wegener Institute for Polar and Marine Research, BAH/AWI, Germany).

\section{Experimental conditions (captive individuals): fed and food-deprived}

All of the animals were maintained for $90 \mathrm{~d}$ prior to the tissue sampling and oxygen consumption experiments under standard $12 \mathrm{~h} / 12 \mathrm{~h}$ light/dark conditions, which are typical of the spring at the latitude of Catalonia, at an intensity that mimics the intensity at a depth of $400 \mathrm{~m}$ (i.e. 0.1 lux; Chiesa et al., 2010). The lobsters were housed in individual cells $(20 \times 30 \times 10 \mathrm{~cm})$ to avoid cannibalism, especially in the food-deprived group (Sardà \& Valladares, 1990). The mesh cells were suspended in a rectangular tank with a capacity of $2000 \mathrm{~L}$. The seawater was continuously aerated and maintained at a temperature of $13 \pm 0.1^{\circ} \mathrm{C}$ and a salinity of $37.5 \pm$ $0.5 \mathrm{psu}$ (physical conditions at a depth of $400 \mathrm{~m}$ in the western Mediterranean; Hopkins, 1984). The F and FD animals were housed separately in two different experimental tanks to avoid feeding contamination between the groups. The $\mathrm{F}$ animals were fed on alternate days with pieces of mussels, fish and squid at a ratio of $0.5 \mathrm{~g}$ per animal, as previously indicated by Sardà \& Valladares (1990). Food was provided for $90 \mathrm{~d}$, and the animals in the fed group were deprived of food for $1 \mathrm{~d}$ before tissue sampling.

\section{Determination of tissue weight and water content}

The tissues (hepatopancreas and deep abdominal flexor muscle, which is hereafter referred to as 'muscle') were weighed after dissection. After drying for $24 \mathrm{~h}$ in an oven at $60^{\circ} \mathrm{C}$, the dry mass (DM) was determined on a Sartorius $\mathrm{BP}_{211} \mathrm{D}$ (Sartorius SA, Göttingen, Germany) balance to the nearest $0.001 \mathrm{mg}$. The water content (WC) was calculated based on the percentage of dry to wet mass (WM) using the following formula:

$$
W C=100\left(1-\frac{D M}{W M}\right)
$$

where DM is the dry mass of the tissue and $\mathrm{WM}$ is the wet mass of the tissue.

\section{Proximal analyses}

The hepatopancreas and muscle tissues that were extracted for proximate biochemical analysis were maintained frozen at $-80^{\circ} \mathrm{C}$ until analysis. Tissue homogenization was attained after the tissues were disrupted for $5 \mathrm{~min}$ with an Ultra Turrax T-25 (IKA ${ }^{\circledR}$ Werke, Germany). All of the methods for proximate biochemical analyses were conducted using a microplate procedure, and the content was estimated in 
triplicate through colourimetric analyses. The homogenates were diluted 1:400, and the protein content in the diluted homogenates was quantified using the method developed by Lowry et al. (1951) with slight modifications. The protein concentrations were determined and reported using bovine serum albumin (BSA) as the standard. A series of dilutions with a known concentration (from o to $40 \mu \mathrm{g} \mathrm{mL}^{-1}$ ) of BSA were prepared and assayed alongside the unknown(s) before the concentration of each unknown was determined based on the standards. In each well, $40 \mu \mathrm{L}$ of the sample or standard was added and incubated for $10 \mathrm{~min}$ with $200 \mu \mathrm{L}$ of reagent $\mathrm{C}(98 \mathrm{ml}$ alkaline carbonate $+1 \mathrm{~mL}$ cupric sulphate 5-hydrate $+1 \mathrm{~mL}$ sodium potassium tartrate 4-hydrate) at room temperature. A total of $20 \mu \mathrm{L}$ of $1 \mathrm{~N}$ Folin-Ciocalteu reagent was then added, and the mixture was allowed to incubate for $30 \mathrm{~min}$ at room temperature in the dark. With the spectrophotometer set to $630 \mathrm{~nm}$, the samples and the standard curve were measured. Distilled water was used as the blank. The carbohydrate content was analysed using the method described by Dubois et al. (1956). The muscle and hepatopancreas homogenates were diluted 1:100 and 1:250, respectively. The carbohydrate concentrations were determined and reported using glucose (from o to $200 \mu \mathrm{g} \mathrm{mL}^{-1}$ ) as the standard. In separate wells, $200 \mu \mathrm{L}$ of homogenate or standard was mixed with $200 \mu \mathrm{L}$ of $5.4 \%$ phenol reagent. Then, $1 \mathrm{~mL}$ of sulphuric acid was added. After the mixture was allowed to cool for $30 \mathrm{~min}$ to $1 \mathrm{~h}, 250 \mu \mathrm{L}$ of the mixture was transferred to a microplate and read at $490 \mathrm{~nm}$. The total lipid content was measured using a Merckotest 3321 kit with the Zöllner \& Kirsch (1962) method, based on the so-called sulphophosphovanillin reaction. First, $80 \mu \mathrm{L}$ of the homogenate was extracted with $500 \mu \mathrm{L}$ of a chloroformmethanol (2:1) mixture. The mixture was then incubated for 10 minutes at room temperature. The tubes were then centrifuged at $10,000 \times \mathrm{g}$ and $4{ }^{\circ} \mathrm{C}$ for $10 \mathrm{~min}$. Then, $300 \mu \mathrm{L}$ of the organic phase was collected, transferred to a new tube, and incubated for $1 \mathrm{~h}$ at $56^{\circ} \mathrm{C}$. The dry extracted lipid was then mixed with $200 \mu \mathrm{L}$ of sulphuric acid and incubated for $10 \mathrm{~min}$ at $95^{\circ} \mathrm{C}$. After the solution reached room temperature (approximately $20 \mathrm{~min}$ ), the lipid content was quantified. We prepared the standard curve with the lipid standard solution contained in the kit (from o to $10 \mu \mathrm{g} \mu \mathrm{L}^{-1}$ ). We added $30 \mu \mathrm{L}$ of the sample of standard to two microplates. To the first plate, we added $350 \mu \mathrm{L}$ of the colour reagent (8 $\mu$ mole $\mathrm{L}^{-1}$ vanillin in 11.9 mole $\mathrm{L}^{-1}$ phosphoric acid solution); to the second plate, we added $350 \mu \mathrm{L}$ of $11.9{\text { mole } \mathrm{L}^{-1}}^{-1}$ phosphoric acid. Both plates were incubated for $40 \mathrm{~min}$ at room temperature and read at $530 \mathrm{~nm}$. The values from the second plate were subtracted from the values obtained for the first plate, and the lipid concentrations of the unknown samples were calculated using the standard curve. The content of each biochemical component was calculated as a percentage of the wet weight.

\section{RNA/DNA ratio}

The RNA and DNA in the muscle and hepatopancreas samples were analysed using the techniques described by Clemmensen (1993) and Moksness et al. (2000) with slight modifications. The lyophilized tissue was rehydrated in Tris-SDS buffer (0.05 M Tris, $0.01 \mathrm{M} \mathrm{NaCl}$, 0.01 M EDTA and $0.01 \%$ SDS) for $15 \mathrm{~min}$. The samples were maintained on ice as they were homogenized with a sonicator for a few seconds to prevent the possible degradation of the genetic material. The homogenate was centrifuged at $6000 \mathrm{r} / \mathrm{min}$ $\left(3830 \mathrm{~g}\right.$ ) and a temperature of $4^{\circ} \mathrm{C}$ for $8 \mathrm{~min}$. The supernatant was divided into two aliquots: one was used to measure the total amount of nucleic acids, and the other was used to measure the DNA. The DNA was measured through RNA digestion by RNase (Ribonuclease $\mathrm{A}$, from a bovine pancreas; SERVA 34388). The RNA fluorescence was calculated by subtracting the DNA fluorescence from the total quantity of nucleic acids. The concentration of nucleic acids was measured through fluorimetry using a spectrofluorometer with an excitation wavelength of $365 \mathrm{~nm}$ and an emission wavelength of $590 \mathrm{~nm}$. Ethidium bromide (EB; 3,8-diamino-6phenyl-5-ethylphenantridium bromide; SERVA 31238) was used as the fluorophore.

\section{Histological procedures}

For the light microscopy analyses, the muscle and hepatopancreas tissues were fixed in Bouin's solution for 24-48 h. The tissues were rinsed and stored in $70 \%$ ethanol until processing. The tissues were dehydrated with increasing concentrations of alcohol $(70 \%(3 \mathrm{~h}), 96 \%(1 \mathrm{~h})$ and twice in $100 \%(1 \mathrm{~h}))$, followed by a $1 \mathrm{~h}$ wash with a $1: 1$ mixture of $100 \%$ ethanol and xylene and two $1 \mathrm{~h}$ washes with xylene. The tissues were then immersed in two consecutive paraffin baths $(3$ and $11 \mathrm{~h})$ and embedded in paraffin. Sections of $6 \mu \mathrm{m}$ were cut on a Leica RM 2155 rotary microtome, and the hepatopancreas and muscle sections were stained with Harris's hematoxylin-eosin and iron hematoxylin, respectively. The sections were observed and photographed under an Olympus BX61 light microscope using bright field optics connected to an Olympus DP70 camera. More than 100 cells of the hepatopancreas were measured to obtain the diameter of the cells, the number of vacuoles, and the number of pyknotic nuclei. The diameter of the cells was measured in $\mu \mathrm{m}$ and only in those cells in which the nucleus was clearly distinguished. The number of vacuoles was counted per hepatopancreas tubule section. The number of pyknotic nuclei was counted and expressed as a percentage relative to the number of cells observed. In the muscle tissues, the distance between sarcomeres was measured. Because the distances were very short, we counted the number of sarcomeres within a fixed distance (a portion of the fibre that was straight), and we calculated the distance between the sarcomeres in $\mu \mathrm{m}$. More than 20 fibres were observed, and the sarcomeres were counted. The measurements and counting were performed using an OPTIMAS 6.0 analyser.

\section{Oxygen consumption}

The oxygen consumption was measured in captive (F and FD) and wild males. The oxygen consumption measurements were conducted in wild individuals caught in the spring $(\mathrm{N}=7)$ and in the captive individuals after the treatments ( $F, N=$ 7; $\mathrm{FD}, \mathrm{N}=5$ ). Due to technical problems with the respirometer, the oxygen consumption measurements were only conducted in the lobsters caught in the spring. At the beginning of each test, the specimens were transferred to individual sealed $1 \mathrm{~L}$ or $2 \mathrm{~L}$ respiratory chambers (the capacity depended on the size of the animals) filled with filtered and $\mathrm{O}_{2}$-saturated seawater. The water temperature and salinity were $13 \pm 1{ }^{\circ} \mathrm{C}$ and $37.5 \pm 0.5 \mathrm{psu}$, respectively. The tests were performed 
inside isolated constant-temperature rooms to avoid any external noise. The temperature was maintained at $13^{\circ} \mathrm{C}$ throughout the experiments. The oxygen consumption was monitored at a sampling frequency of $3.14 \mathrm{~min}$ using a fibre-optic microsensor in a Microx-8 oxygen meter (PreSens GmbH, Neuburg, Germany; Precision Sensing, 1999). An empty respiratory chamber was used as a control in all tests to determine the water microbial biomass respiration (Company \& Sardà, 1998). The data for each chamber, which were recorded as a percentage of the saturation of the oxygen partial pressure $\left(\mathrm{pO}_{2}\right)$, were automatically stored in a computer.

No food was provided before or during the experiments to avoid exogenous variation in oxygen consumption due to the digestion process, which is known to affect the internal metabolism (Ansell, 1973; Crear \& Forteath, 2000). All of the measurements that refer to the individual animal's size (CL, $\mathrm{mm}$ ), wet mass (WM, $\mathrm{g}$ ), and body volume ( $\mathrm{mL}$, estimated by water volume displacement) were obtained at the end of the tests to avoid the effects of handling stress.

To measure the differences in oxygen consumption between the captive animals subjected to the different feeding treatments (F and FD) and the wild animals, the timeseries data obtained throughout the experiment were graphically represented at the sampling time scale of $3.14 \mathrm{~min}$. The critical point $(\mathrm{Pc}$, the critical oxygen partial pressure below which the animal's respiration is no longer independent from the concentration of this gas in the water (Prosser, 1973)) was identified for the majority of the time-series data. The $\mathrm{pO}_{2}$ data points below the Pc were omitted from further analyses. In a few cases, high oxygen consumption values were recorded at the beginning of the experiments, most likely due to handling stress. Therefore, these values were also omitted from further analyses.

The computed oxygen consumption rates were transformed into $\mu \mathrm{mol}$ based on the following relationship: $100 \%$ $\mathrm{pO}_{2}$ equals $260.6 \mu \mathrm{mol}$ at $1 \mathrm{~atm}, 13^{\circ} \mathrm{C}$, and 37.5 salinity (Endeco/YSI, Inc., 1992). The time-series data were subjected to a linear regression analysis to calculate the slope as an estimate of the mass-specific rate of oxygen consumption by each individual $\left(\mathrm{MO}_{2}\right)$. The presence of a significant slope change was considered an indication of intra-individual variation in the oxygen consumption rate depending on the feeding treatment. To assess the differences in Nephrops respiration depending on the experimental group (F, FD and wild), the mass-specific oxygen consumption rates were obtained. To avoid the effect of size on the metabolic rates, a scaling coefficient of -0.2 was assumed (Childress \& Somero, 1979). Thus, the $\mathrm{MO}_{2}$ data were provided as the animal mass-specific rates of oxygen consumption at a time scale of one hour ( $\mu \mathrm{mol} \mathrm{O} \mathrm{O}^{-1} \mathrm{WM} \mathrm{h}^{-1}$ ) and then corrected to a standard animal mass of $20 \mathrm{~g}$ using the above mentioned size scaling coefficient.

\section{Statistical analysis}

The datasets were analysed and plotted using the SigmaPlot 9 and SigmaStat 3 software packages (Systat Software Inc., Chicago, USA). The differences in the biochemical composition, the morphological changes in the hepatopancreas and muscle, and the oxygen consumption among seasons and feeding treatments were tested with a one-way ANOVA. In this analysis, the conditions ( $F$ and FD) and seasons were treated as independent factors in both the laboratory and field animals (to evaluate the differences between these two groups at the same time). If significant differences were found, the groups were compared using a Holm-Sidak test with an overall significance level of $P<0.05$. The normal distribution of the data was confirmed with a KolmogorovSmirnov normality test.

\section{RESULTS}

In the laboratory experiments, the survival of the fed $(F)$ and the food-deprived (FD) animals was $84.2 \%$ and $85.7 \%$, respectively, after $90 \mathrm{~d}$ in captivity. The lipid concentration in the hepatopancreas and muscles of the F and FD lobsters presented the highest and the lowest values, respectively, and the wild lobsters exhibited concentrations within this range. In the hepatopancreas, the water content and morphological characteristics analysed exhibited a similar trend. The specific differences in biochemical and morphological characteristics among the groups are detailed below.

\section{Water content and proximal analyses}

The differences between the feeding treatments and the seasons in the water content and proximal analyses measured in the hepatopancreas and muscle are summarized in Figure 1. The water content in the hepatopancreas of the FD lobsters (78.6\%) was significantly higher than that of the F animals. The wild lobsters collected in the spring also showed a high percentage of water in the hepatopancreas (74.1\%). The lowest water content in the hepatopancreas was found in the lobsters caught in the winter and autumn, and these values were significantly different from those of the spring and FD groups $\left(\mathrm{F}_{5,54}=8.214 ; P<0.001\right)$.

The protein content in the hepatopancreas was significantly lower in the lobsters caught in the winter (11.86 $\pm 1.15 \%)$ compared with those caught in the spring (14.43 $\pm 1.90 \%)$. The protein content in the former was even lower than that reported in the FD animals, although the difference was not significant $\left(\mathrm{F}_{5,54}=2.920 ; P=0.021\right)$. The lipid content in the hepatopancreas of the FD animals $(1.86 \pm 1.89 \%)$ was 10-fold lower than that of the $\mathrm{F}$ animals and the wild animals. The wild animals did not exhibit any significant differences among any of the seasons and in comparison with the fed animals $\left(\mathrm{F}_{5,54}=17.830 ; P<0.001\right)$. The carbohydrate concentration in the hepatopancreas of the males in the $\mathrm{F}$ group exhibited the highest value $(2.25 \pm 0.55 \%)$, and this value was significantly higher than those obtained for the other groups with the exception of the lobsters caught in the spring $\left(1.61 \pm 0.38 \% ; \mathrm{F}_{5,54}=11.204 ; P<0.001\right)$.

The muscle water content was higher in the animals caught in the spring $(80.43 \pm 3.16 \%)$, although this value was not significantly different from the content observed in the FD animals $(78.66 \pm 1.90 \%)$. Lower values were observed in the lobsters caught in the winter and autumn, but these values were not significantly different from that of the $\mathrm{F}$ animals $\left(\mathrm{F}_{5,54}=8.735 ; P<0.001\right)$. No significant differences were observed in the protein content of the muscles of the $\mathrm{F}$ and FD animals, and these values were between the protein levels in the muscles of the animals caught in the autumn $(15.41 \pm 0.77 \%)$ and those of the animals caught in the summer $\left(12.54 \pm 1.16 \% ; \mathrm{F}_{5,54}=2.969 ; \quad P=0.019\right)$. The 

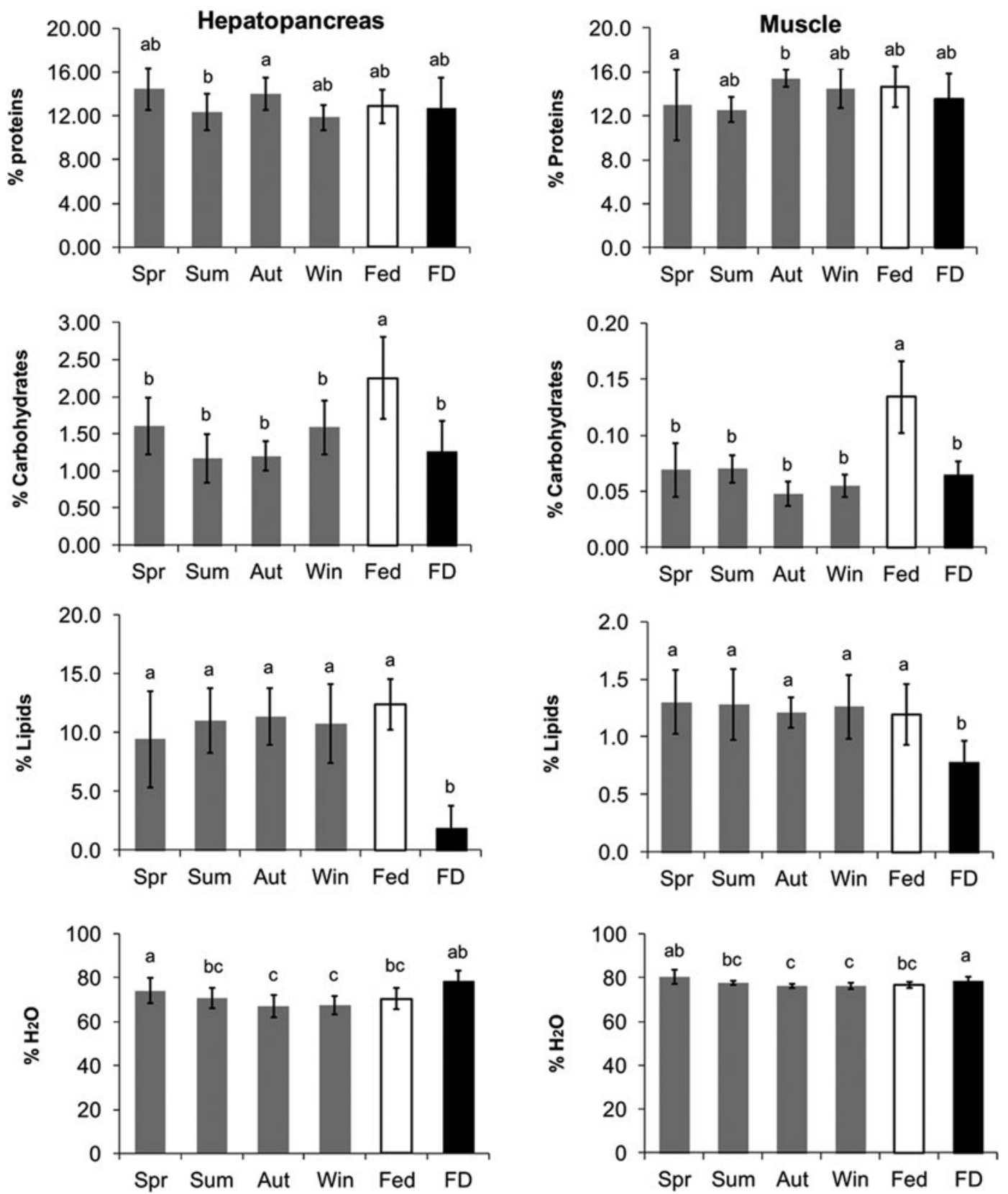

Fig. 1. Proximal composition and water content in the hepatopancreas and muscle (percentage of wet mass) of wild (Spr, spring; Sum, summer; Aut, autumn; Win, winter) and captive (9o d; F, fed; FD, food-deprived) Nephrops norvegicus males. The significant differences among the groups are indicated with a superscript letter (ANOVA, Holm-Sidak, $P<0.001$ ).

food-deprived lobsters exhibited the lowest lipid content $(0.78 \pm 0.18 \%)$, and this value was significantly different from all of the other groups. The highest lipid content was obtained in the muscle of the lobsters caught in the spring $(1.30 \pm 0.28 \%)$, but no significant differences were observed in the muscle lipid content between the animals caught in any other season or fed in captivity $\left(\mathrm{F}_{5,54}=6.250 ; P<\right.$ 0.001 ). Low levels of carbohydrates were found in the abdominal muscle of all of the lobsters. The fed lobsters presented the highest level of carbohydrates in the abdominal muscle $(0.13 \pm 0.03 \%)$, and this value was significantly different from those measured in the FD group and in the wild animals caught in any of the seasons $\left(\mathrm{F}_{5,54}=27.070\right.$; $P<0.001)$

\section{Morphological changes in the hepatopancreas and muscle}

Morphological differences were observed in the hepatopancreas and muscle between the captivity treatments and the seasons (Table 1). The fed lobsters presented the highest number of vacuoles per tubule $(7.72 \pm 2.91)$, whereas the FD group exhibited the lowest values (1.20 \pm 0.52 ; Figure 2). The number of vacuoles in the lobsters caught in the summer was significantly higher than that observed in those sampled at all other seasons but not significantly higher than that in the F lobsters. The lobsters caught in the winter and autumn showed a low number of vacuoles $(3.26 \pm 2.04$ and $3.75 \pm 0.81$, respectively), but this value 
Table 1. Morphological characteristics of hepatopancreas and muscle from wild (spring, summer, autumn and winter) and captive (fed and food deprived during 90 days) males of Nephrops norvegicus. Significant differences between groups are indicated by superscript letters (ANOVA, Holm-Sidak, $P<0.001)$.

\begin{tabular}{|c|c|c|c|c|c|c|}
\hline & Spring & Summer & Autumn & Winter & Fed & Food deprived \\
\hline \multicolumn{7}{|l|}{ Hepatopacreas } \\
\hline $\mathrm{N}^{\circ}$ vacuoles & $2.81 \pm 2.05^{b c}$ & $6.20 \pm 3.63^{\mathrm{a}}$ & $3.75 \pm 0.81^{b}$ & $3.26 \pm 2.04^{\mathrm{b}}$ & $7.72 \pm 2.91^{\mathrm{a}}$ & $1.20 \pm 0.52^{\mathrm{c}}$ \\
\hline Cell high $(\mu \mathrm{m})$ & $53.39 \pm 5.23^{\mathrm{b}}$ & $69.36 \pm 15.77^{\mathrm{a}}$ & $53.44 \pm 8.16^{\mathrm{b}}$ & $61.10 \pm 9.60^{\mathrm{ab}}$ & $41.84 \pm 4.75^{\mathrm{c}}$ & $22.09 \pm 7.76^{\mathrm{d}}$ \\
\hline $\begin{array}{l}\text { Pyknotic nuclei (\%) } \\
\text { Muscle }\end{array}$ & $0.19 \pm 0.39^{\mathrm{b}}$ & $0.00 \pm 0.00^{b}$ & $0.12 \pm 0.24^{b}$ & $0.00 \pm 0.00^{b}$ & $0.00 \pm 0.00^{b}$ & $2.65 \pm 4.13^{\mathrm{a}}$ \\
\hline Sarcomeres $(\mu \mathrm{m})$ & $6.05 \pm 2.48^{\mathrm{ab}}$ & $5.03 \pm 0.87^{\mathrm{ab}}$ & $4.87 \pm 0.97^{\mathrm{ab}}$ & $4.32 \pm 0.50^{\mathrm{b}}$ & $4.78 \pm 1.78^{\mathrm{ab}}$ & $6.60 \pm 2.09^{\mathrm{a}}$ \\
\hline
\end{tabular}

A

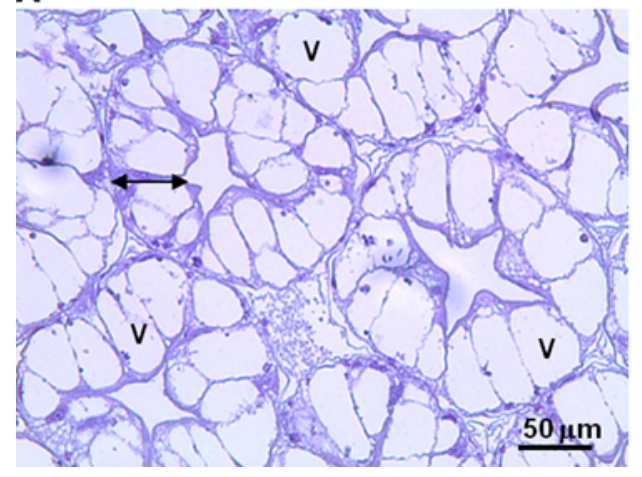

B

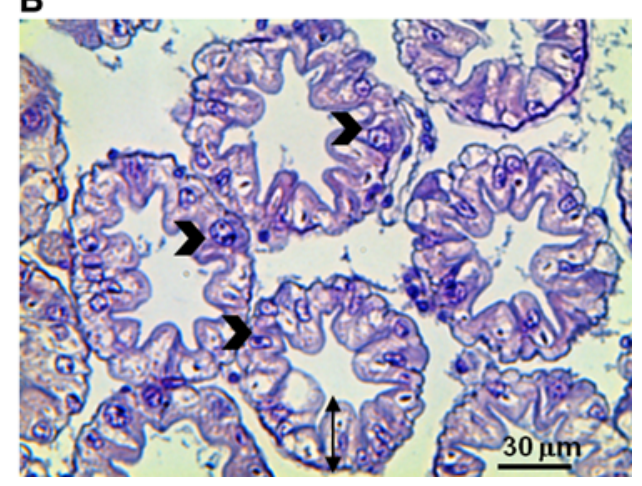

Fig. 2. Hepatopancreas image from fed (A) and food-deprived (B) Nephrops norvegicus males kept in captivity for 90 d. V, vacuoles; arrow, cell high; arrowhead, pyknotic nucleus.

was significantly higher than that reported for the FD animals $\left(\mathrm{F}_{5,54}=11.015 ; P<0.001\right)$. The FD lobsters exhibited the smallest hepatopancreas cells $(22.09 \pm 7.76 \mu \mathrm{m})$, and this size differed significantly from that of the $\mathrm{F}$ lobsters $(41.84 \pm 4.75 \mu \mathrm{m})$. However, the wild lobster cells were significantly larger than those of both the F and the FD animals. The hepatopancreatic cells in the lobsters caught in the summer $(69.36 \pm 15.77 \mu \mathrm{m})$ were larger than those of the lobsters caught in any of the other seasons, and their size differed significantly from that of the spring and autumn groups $\left(\mathrm{F}_{5,54}=31.686 ; P<0.001\right)$.

Few pyknotic nuclei were observed in the cells of the hepatopancreas of the FD animals $(2.65 \pm 4.13 \%)$, and this number was significantly greater than that obtained for all of the other groups $\left(\mathrm{F}_{5,54}=3.901 ; P=0.004\right)$. Pyknotic nuclei were occasionally observed in the hepatopancreatic cells of the male lobsters caught in the spring and autumn.
The muscle of the FD lobsters showed the largest sarcomere sizes $(6.60 \pm 2.09 \mu \mathrm{m})$, and this length was significantly greater than that observed in the muscle of the lobsters caught in the winter $\left(4.32 \pm 0.50 \mu \mathrm{m} ; \mathrm{F}_{5,54}=2.869 ; P=0.023\right)$.

\section{RNA/DNA in the hepatopancreas and muscle}

The RNA/DNA ratios in both studied tissues were significantly lower in the males kept in captivity (both F and FD) than in the freshly caught males (Figure 3 ). The fed animals presented a higher RNA/DNA ratio than the FD lobsters, but the differences were not significant. No significant differences in this ratio were observed in the hepatopancreas of the wild animals $\left(\mathrm{F}_{5,54}=11.479 ; P<0.001\right)$. In contrast, the muscle of the animals caught in the spring exhibited significantly higher RNA/DNA ratios $(2.55 \pm 0.50)$ than that of those caught in the other seasons, and the lobsters caught in the
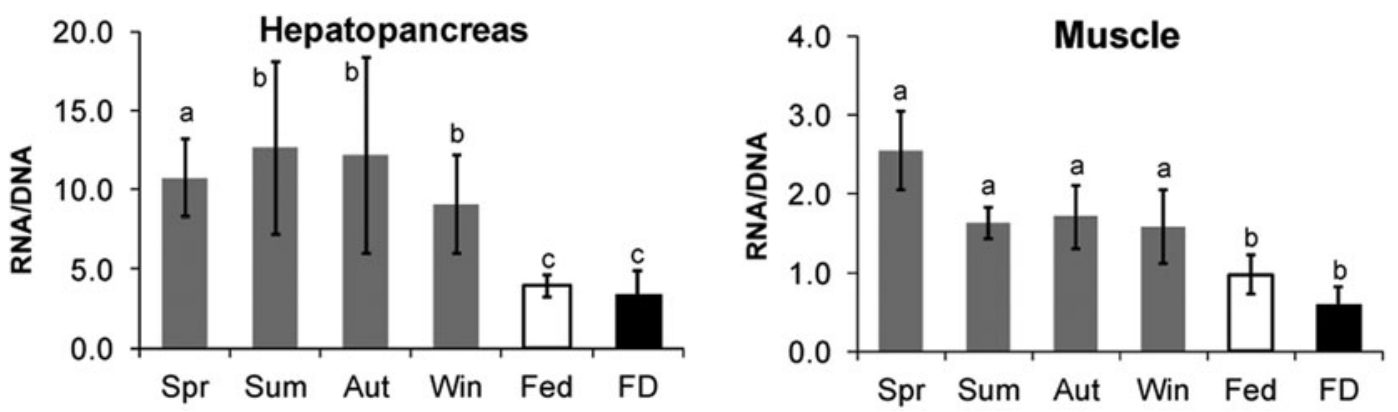

Fig. 3. RNA/DNA ratio in the hepatopancreas and muscle (percentage of wet mass) of wild (Spr, spring; Sum, summer; Aut, autumn; Win, winter) and captive ( $90 \mathrm{~d}$; F, fed; FD, food-deprived) Nephrops norvegicus males. The significant differences among the groups are indicated with a superscript letter (ANOVA, HolmSidak, $P<0.001$ ). 
Table 2. Mass-specific rate of oxygen consumption rates $\left(\mathrm{MO}_{2}\right)$ from captive (food deprived and fed during $90 \mathrm{~d}$ ) and wild (spring) males of Nephrops norvegicus. FD: Food deprived. Significant differences among groups are indicated by superscript letters (ANOVA, Holm-Sidak, $P<0.001$ ). $M \mathrm{O}_{2}$ marked with an asterisk correspond to the rates represented in Figure 4.

\begin{tabular}{|c|c|c|c|c|c|c|c|c|c|}
\hline & \multicolumn{3}{|c|}{ Wet mass (WM, g) } & \multicolumn{3}{|c|}{ 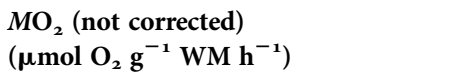 } & \multicolumn{3}{|c|}{ 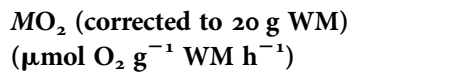 } \\
\hline & \multicolumn{2}{|c|}{ Captive } & \multirow{2}{*}{$\begin{array}{l}\text { Wild } \\
\text { Spring }\end{array}$} & \multicolumn{2}{|c|}{ Captive } & \multirow{2}{*}{$\begin{array}{l}\text { Wild } \\
\text { Spring }\end{array}$} & \multicolumn{2}{|c|}{ Captive } & \multirow{2}{*}{$\begin{array}{l}\text { Wild } \\
\text { Spring }\end{array}$} \\
\hline & Fed & FD & & Fed & FD & & Fed & FD & \\
\hline & 29.2 & 11.2 & 17.0 & 3.3317 & $0.5138^{*}$ & 1.6807 & 3.5936 & 0.4576 & 1.6269 \\
\hline & 22.7 & 14.2 & 29.2 & 1.0219 & 0.6370 & 1.8042 & 1.0488 & 0.6579 & 1.9460 \\
\hline & 12.5 & 40.8 & 25.4 & $2.0703^{*}$ & 0.4904 & $1.8784^{*}$ & 1.8845 & 0.5655 & 1.9704 \\
\hline & 24.1 & 13.7 & 28.0 & 3.3705 & 0.5066 & 1.2698 & 3.4985 & 0.4696 & 1.3582 \\
\hline & 30.4 & 20.0 & 26.8 & 1.7710 & 0.4895 & 2.1454 & 1.9257 & 0.4895 & 2.2747 \\
\hline & 37.2 & & 21.1 & 2.7183 & & 2.2967 & 3.0775 & & 2.3214 \\
\hline & 24.8 & & 17.2 & 2.0228 & & 2.1929 & 2.1117 & & 2.1277 \\
\hline Mean $( \pm S D)$ & 25.8 & 20.0 & 23.5 & 2.3295 & 0.5275 & 1.8954 & $2.4486^{\mathrm{a}}$ & $0.5280^{\mathrm{b}}$ & $\begin{array}{l}1.9465^{\mathrm{a}} \\
(0.3488)\end{array}$ \\
\hline
\end{tabular}

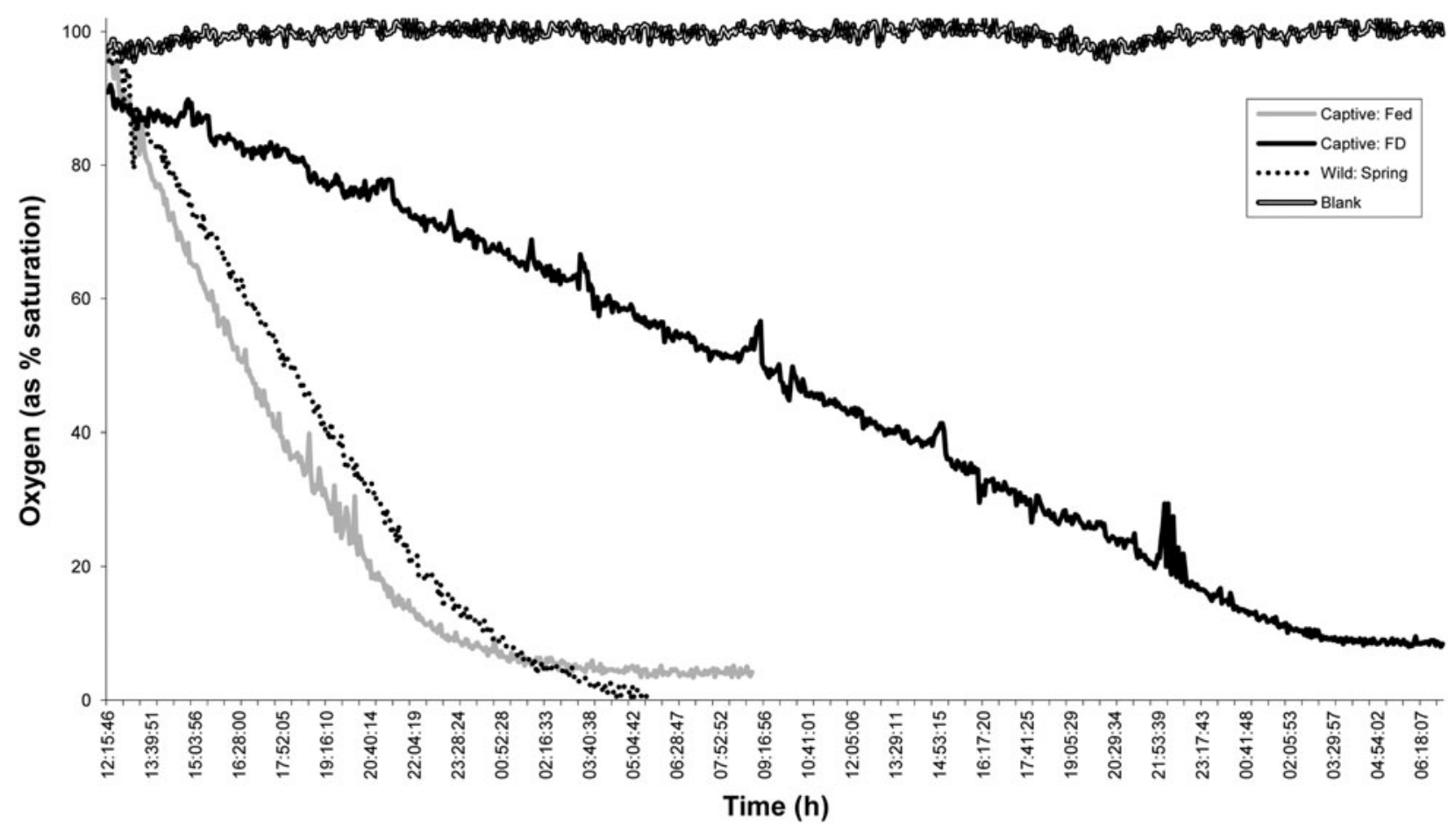

Fig. 4. Oxygen consumption rates of wild (Spr, spring) and captive (9o days; F, fed; FD, food-deprived) Nephrops norvegicus males. The oxygen consumption curves shown correspond to those obtained for the animals that exhibited the measurements that were closest to the average values of each group; these animals are indicated with an asterisk in Table 2. The significant differences among the groups are indicated with a superscript letter (ANOVA, Holm-Sidak, $P<0.001)$.

winter exhibited the lowest ratio $\left(1.58 \pm 0.46 ; \mathrm{F}_{5,54}=34.845\right.$; $P<0.001)$

\section{Oxygen consumption}

The fed animals consumed more oxygen $(2.4486 \pm$ $\left.0.9552 \mu \mathrm{mol} \mathrm{O}_{2} \mathrm{~g}^{-1} \mathrm{WM} \mathrm{h}^{-1}\right)$ than the FD animals $\left(0.5280 \pm 0.0839 \mu \mathrm{mol} \mathrm{O} \mathrm{g}^{-1} \mathrm{WM} \mathrm{h}^{-1}\right)$. The wild animals caught in the spring exhibited intermediate consumption rates compared with the $\mathrm{F}$ and $\mathrm{FD}$ animals, but these rates were only significantly different from the rates obtained for the food-deprived group $\left(1.9465 \pm 0.3488 \mu \mathrm{mol} \mathrm{O}_{2} \mathrm{~g}^{-1} \mathrm{WM} \mathrm{h}^{-1}\right.$; $\mathrm{F}_{16,2}=14.314 ; P<0.001$; Table 2; Figure 4).

\section{DISCUSSION}

This paper provides the first demonstration of the absence of seasonal variation in the nutritional condition of western Mediterranean Nephrops norvegicus at the histological, physiological, biochemical and molecular levels. The fooddeprived animals showed higher water content in the hepatopancreas and muscle, although differences in the muscle were not significant. Our results indicate that the lipid and carbohydrate content in Nephrops decrease concomitantly after 3 months of starvation, whereas the protein content remains fairly stable. We propose that carbohydrates are used in shortterm starvation and that the lipid reserve is then accessed 
either from the hepatopancreas or the muscle, although the major reserve is obtained from the latter. The protein reserve appears not to be used for at least 3 months of food deprivation. This mechanism allows Nephrops to compensate for seasonal fluctuations in the local input of organic matter.

In Nephrops, the uptake from the metabolic reserve starts from the hepatopancreas and not from the muscle. The reserve role of the former organ has also been described in other crustaceans (Gibson \& Barker, 1979). The metabolic reserves within the body of crustaceans, such as lipids, proteins and carbohydrates, could be utilized to provide energy when the animals are starving. Additionally, decapods activate water intake upon starvation to maintain their body volume and the turgidity of their tissues (Comoglio et al., 2005). Sanchez-Paz et al. (2006) emphasized the diversity of physiological resources used by decapod crustaceans during starvation. For example, the prawn Marsupenaeus japonicus (Cuzon et al., 1980) first utilizes its glycogen reserves, whereas the varunid crab Hemigrapsus nudus (Neiland \& Scheer, 1953) utilizes proteins. In Nephrops, the hepatopancreatic lipid content does not decrease within the first $18 \mathrm{~d}$ of starvation, although a change in fatty acid composition might occur (Dall, 1981), suggesting an adaptive decrease in the metabolic rate to ensure lipid preservation. Mente (2010) demonstrated that $N$. norvegicus fed a mussel diet exhibit higher hepatopancreas lipid concentrations than lobsters that were starved for 6 months, and these results are similar to those obtained in our study. The protein content in the tail muscle of $N$. norvegicus has also been found not to decrease significantly after $12 \mathrm{wk}$ and 6 months of starvation (Parslow-Williams, 1998), and this finding is also in agreement with our results. In contrast, glycogen is depleted in both the tail and the hepatopancreas after 7 months of starvation (Baden et al., 1994), and this depletion is particularly intense from weeks 4 to 12 in the tail and the hepatopancreas (Watts, 2012). In our study, the carbohydrate content was higher in captive-fed animals compared to FD or wild Nephrops, indicating that the levels of carbohydrates were due to the high level of carbohydrates present in mussels (the food provided) compared with the prey captured in the field by wild animals (Karakoltsidis et al., 1995).

We found the lowest lipid and the highest water content in the hepatopancreas in the lobsters caught in the spring and an opposite pattern in the lobsters caught in the summer, and these findings are similar to those reported for the lobster population in the Atlantic (Parslow-Williams, 1998). However, the hepatosomatic indices did not vary significantly between these two seasons. The lipid content of the muscle in the male lobsters exhibited significant seasonal variations that increased considerably in May (Rosa \& Nunes, 2002). The males caught during the spring of 2009 had a decreased nutritional status, as indicated by the higher water content in the hepatopancreas and the lower lipid content and protein level in the tail muscle compared with those captured during the second half of the year (Watts, 2012). However, these differences were not observed in the replicate sampling performed during 2010.

In our study, the RNA/DNA ratio in the muscle was significantly higher in the lobsters caught in the spring and lowest in the lobsters caught in the winter, but this ratio remained constant in the hepatopancreas. Spring is the period when Nephrops exhibits its maximal reproductive activity in our study area, and this period also corresponds to a peak in post-moult activity because both processes are related to growth. The observations that the RNA concentration was lower in the muscle of captive animals and that the RNA/ DNA ratio was thus two-fold higher in the wild animals indicate that laboratory confinement reduced the growth capacity of the animals. The limitation of growth by confinement has been shown in other decapod crustaceans (Wilber \& Wilber, 1989).

In our study, the morphological characteristics of the hepatopancreas cells also allowed the differentiation of Nephrops caught during the different seasons: the males caught in the summer showed the highest number of vacuoles, the largest cells, and an absence of pyknotic nuclei. Additionally, significantly lower values in the diameter of the hepatopancreatic cells and the number of vacuoles and the highest number of pyknotic nuclei were observed in the FD animals. Starvation of $N$. norvegicus produces external colour variations (Sardà \& Valladares, 1990), which are correlated with changes in the hepatosomatic index (Watts, 2012). The rapid depletion of the hepatopancreas vacuoles and the increase in the number of pyknotic nuclei during starvation have also been documented in other decapods (Vogt et al., 1985; McLeod et al., 2004).

In the present study, the abdominal muscular fibres of the medial bundle were of an intermediate length in Nephrops according to the classification presented by Atwood (1972). Fowler \& Niel (1992) showed that the fibres of the medial bundle in this species have long sarcomeres $\left(>_{9} \mu \mathrm{m}\right)$ and that the majority of the lateral fibres have shorter sarcomeres $(<8 \mu \mathrm{m})$. The medial fibres were $6.6 \pm 2.1 \mu \mathrm{m}$ and $4.8 \pm$ $1.8 \mu \mathrm{m}$ in length in the FD and the F animals, respectively. These length differences could be related to the ecological characteristics of Mediterranean slope and Scottish shelf (>50 m depth) fishing grounds, where Nephrops are known to grow rapidly (Tuck et al., 1997). Although the differences in the sizes of the sarcomeres between the F and FD animals did not differ significantly, the latter may display an increase in water content that leads to an elongation of their fibres. Given this rationale, the animals caught in the winter most likely exhibit the best muscle condition, whereas those caught in the spring present a morphology that is closer to that of the food-deprived animals. These findings represent the first demonstration of the reliability of the muscle morphology of decapods as a nutritional indicator.

The oxygen consumption of the $\mathrm{F}$ animals was four-fold higher than that of the FD animals; however, a previous study conducted in the Atlantic found only a two-fold difference (Parslow-Williams, 1998). The higher rearing temperature used in our study $\left(13^{\circ} \mathrm{C}\right.$ compared with $10^{\circ} \mathrm{C}$ for the Atlantic) and the smaller size of the tested lobsters (mean weight of $20 \mathrm{~g}$ compared with $26 \mathrm{~g}$ in the study conducted in the Atlantic) were the principal differences between these two experiments, suggesting that rearing temperature and animal size might be responsible for this difference. The wild animals caught in the spring presented intermediate values compared with the captive males. Our results were slightly higher than those reported by Aguzzi et al. (2003a) for animals captured in the same area; however, the experimental conditions were different because our tests were not performed in constant darkness (i.e. we used the spring photoperiod). The feeding rates and the quality of the food influence the oxygen consumption in crustaceans (Hewitt \& Irving, 1990; Thomas et al., 2000; Crear \& Forteath, 2002; Perera et al., 2007; Díaz-Iglesias et al., 2011), and a progressive 
decline in oxygen consumption is commonly observed in decapods under starvation (Ansell, 1973; Aldrich, 1975). Although we were unable to find a difference in the oxygen consumption rates between the seasons, this metabolic parameter might be a promising tool to monitor the nutritional condition of $N$. norvegicus.

The nutritional condition indices used in this study showed no differences between the seasons, although the catchability of Nephrops varies seasonally, the male moult period occurs, and the females carry their eggs during the winter, resulting in low gonadosomatic index values (Figure 5). The premoulting period has been identified as a natural fasting period, although it lasts only few days (Vernet \& Charmantier-Daurès, 1994). The low catchability in winter appears to occur because berried Nephrops females remain in their burrows (Aguzzi et al., 2004). Copulation begins in the spring because the eggs deployed in the previous season have just hatched (Rotllant et al., 2005). Copulation lasts until the spawning period in mid-summer, which coincides with the period of maximum catchability in our area.

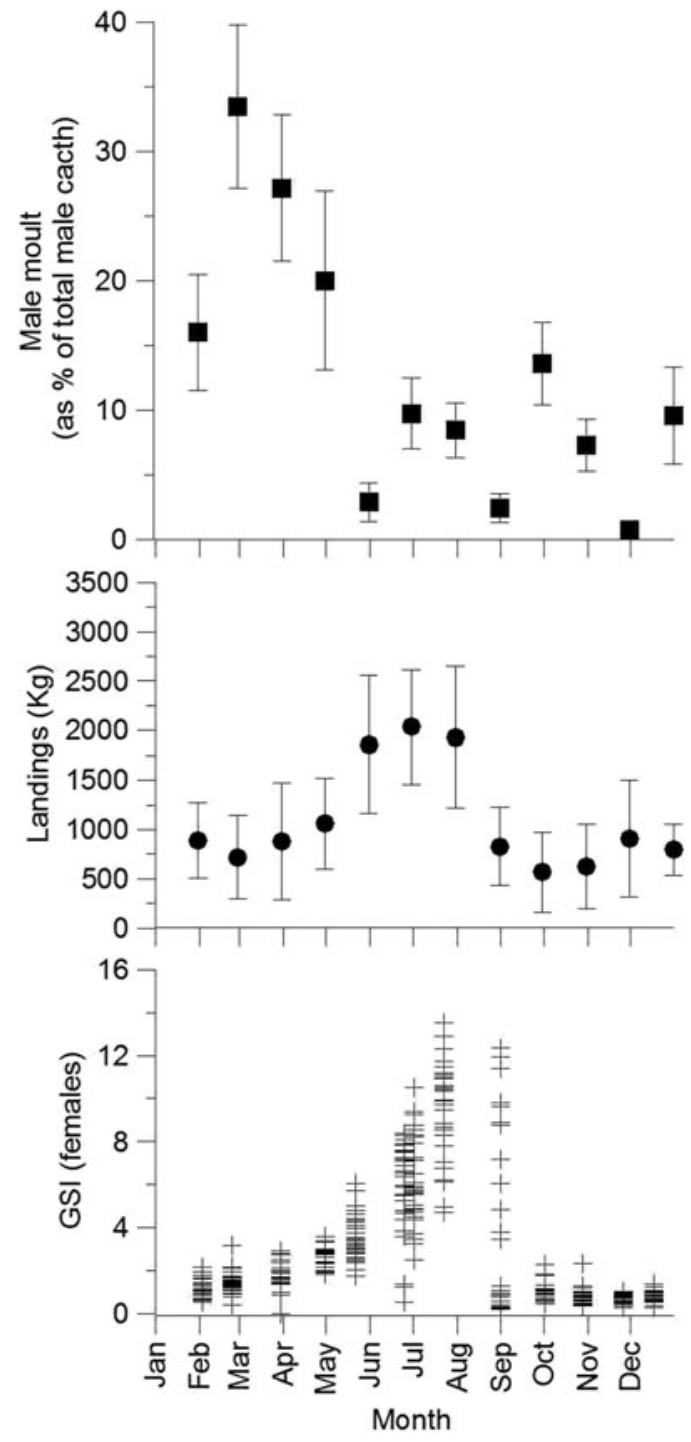

Fig. 5. Annual periods of Nephrops norvegicus: (A) male molting period (modified from Sardà, 1985); (B) landings (modified from Sardà \& Aguzzi, 2012); (C) female gonadosomatic indices (modified from Rotllant et al., 2005).
During spring and summer, it is probable that the Norway lobster spends more time outside the burrows and is, therefore, more vulnerable to bottom fishing nets (Aguzzi et al., 2004). The stomach fullness in the summer has been shown to be higher compared with that in winter (Cristo \& Cartes, 1998). Additionally, the rate of food digestion is $12 \mathrm{~h}$ (Sardà \& Valladares, 1990). In summer, feeding might occur earlier in the day than in winter because the light intensity on the upper slope is higher at that time and the lobster's feeding excursions are driven by this habitat parameter (Chiesa et al., 2010). Cristo \& Cartes (1998) also observed that the stomach contents in the winter show a lower prey diversity than that observed in summer. This difference is produced by the lower input of organic matter in the winter (Heussner et al., 2006). This low food flow at slope depths in the winter may also result in a poor nutritional condition, although we found no clear nutritional evidence of food deprivation in the wild populations during any of the seasons.

In summary, starvation experiments are a useful method for the identification of the best nutritional indices for Nephrops. The nutritional condition of this species was better explained by the lipid concentration in the hepatopancreas and muscle, the water content in the hepatopancreas, and the numbers of vacuoles and pyknotic nuclei in the cells of the tubules of the hepatopancreas. The results obtained in the wild lobsters primarily showed intermediate values between the measurements obtained for the food-deprived lobsters and those obtained for the fed lobsters in captivity. Therefore, the wild animals do not face food deprivation during winter as suggested by the pattern of commercial catches, by the flow of organic matter and by the periodic biological processes characteristic of the species.

\section{ACKNOWLEDGEMENTS}

The authors would like to thank the captains and crews of the FVs 'Maireta III', 'Zorrilla' and 'Francesc i Lluis'. The authors also thank Ms T. Cariou, N. Lujua, I. Palatzi and L. Rodriguez for technical support.

\section{FINANCIAL SUPPDRT}

This paper is a product of the Spanish CICYT Project BIFICRUST (REN2001-0729), which involves L. Fernández and F. Sardà, and was supported by a grant from the Xarxa de Referència de Recerca en Aqüicultura of the Generalitat de Catalunya to G. Rotllant. Jacopo Aguzzi is a Postdoctoral Fellow of the 'Ramon y Cajal' Program (MICINN).

\section{REFERENCES}

Abelló P., Abella A., Adamidou A., Jukic-Peladic S., Maiorano P. and Spedicato M.T. (2002a) Geographical patterns in abundance and population structure of Nephrops norvegicus and Parapenaeus longirostris (Crustacea: Decapoda) along the European Mediterranean coasts. Scientia Marina 66 125-141.

Abello P., Carbonell A. and Torres P. (2002b) Biogeography of epibenthic crustaceans on the shelf and upper slope off the Iberian Peninsula Mediterranean coasts: implications for the establishment of natural management areas. Scientia Marina 66, 183-198. 
Abelló P., Valladares F.J. and Castellón A. (1988) Analysis of the structure of decapod crustacean assemblages off the Catalan coast (North-West Mediterranean). Marine Biology 98, 39-49.

Aguzzi J., Bozzano A. and Sardà F. (2004) First observations on Nephrops norvegicus (L.) burrow densities on the continental shelf off the Catalan Coast (Western Mediterranean). Crustaceana 77, 299-310.

Aguzzi J., Company J.B., Sardà F. and Abelló P. (2003a) Circadian oxygen consumption patterns in continental slope Nephrops norvegicus (Decapoda: Nephropidae) in the western mediterranean. Journal of Crustacean Biology 23, 749-757.

Aguzzi J. and Sardà F. (2008) A history of recent advancements on Nephrops norvegicus behavioral and physiological rhythms. Reviews in Fish Biology and Fisheries 18, 235-248.

Aguzzi J., Sarda F., Abello P., Company J.B. and Rotllant G. (2003b) Diel and seasonal patterns of Nephrops norvegicus (Decapoda: Nephropidae) catchability in the western Mediterranean. Marine Ecology Progress Series 258, 201-211.

Aguzzi J., Sarda F. and Allué R. (2004) Seasonal dynamics in Nephrops norvegicus (Decapoda: Nephropidae) catches off the Catalan coasts (Western Mediterranean). Fisheries Research 69, 293-300.

Aldrich J.C. (1975) Individual variability in oxygen consumption rates of fed and starved Cancer pagurus and Maia squinado. Comparative Biochemistry and Physiology 51A, 175-183.

Ansell A.D. (1973) Changes in oxygen consumption, heart rate and ventilation accompanying starvation in the decapod crustacean Cancer pagurus. Netherlands Journal of Sea Research 7, 455-475.

Atwood H.L. (1972) Crustacean muscle. In Bourne G. (ed.) The structure and function of muscle, Volume 1. New York: Academic Press, pp $421-489$.

Baden S.P., Depledge M.H. and Hagerman L. (1994) Glycogen depletion and altered copper and manganese handling in Nephrops norvegicus following starvation and exposure to hypoxia. Marine Ecology Progress Series 103, 65-72.

Bell M., Redant F. and Tuck I. (2006) Nephrops species. In Phillips B. (ed.) Lobsters: biology, management, aquaculture and fisheries. Oxford: Blackwell, pp. 412-461.

Cartes J.E. and Sarda F. (1993) Zonation of deep-sea decapod fauna in the Catalan Sea (Western Mediterranean). Marine Ecology Progress Series 94, 27-34.

Chiesa J.J., Aguzzi J., García J.A., Sardà F. and de la Iglesia H.O. (2010) Light intensity determines temporal niche switching of behavioral activity in deep-water Nephrops norvegicus (Crustacea: Decapoda) Journal of Biological Rhythms 25, 277-287.

Childress J.J. and Somero G.N. (1979) Depth-related enzymic activities in muscle, brain and heart of deep-living pelagic marine teleosts. Marine Biology 52, 273-283.

Clemmesen C. (1993) Improvements in the fluorimetric determination of the RNA and DNA content of individual marine fish larvae Marine Ecology Progress Series 100, 177-183.

Comoglio L., Smolko L. and Amin O. (2005) Effects of starvation on oxygen consumption, ammonia excretion and biochemical composition of the hepatopancreas on adult males of the False Southern King crab Paralomis granulosa (Crustacea, Decapoda). Comparative Biochemistry and Physiology Part B: Biochemistry and Molecular Biology 140, 411-416.

Company J.B. and Sardà F. (1998) Metabolic rates and energy content of deep-sea benthic decapod crustaceans in the western Mediterranean Sea. Deep-Sea Research I 45, 1861-1880.
Company J.B., Puig P., Sardà F., Palanques A., Latasa M. and Scharek R. (2008) Climate influence on deep sea populations. PLoS ONE 3, e1431. doi:10.1371/journal.pone.0001431.

Crear B.J. and Forteath G.N.R. (2000) The effect of extrinsic and intrinsic factors on oxygen consumption by the southern rock lobster, Jasus edwardsii. Journal of Experimental Marine Biology and Ecology 252, 129-147.

Crear B.J. and Forteath G.N.R. (2002) Feeding has the largest effect on the ammonia excretion rate of the southern rock lobster, Jasus edwardsii, and the western rock lobster, Panulirus cygnus. Aquacultural Engineering 26, 239-250.

Cristo M. and Cartes J.E. (1998) A comparative study of the feeding ecology of Nephrops norvegicus (L.), (Decapoda: Nephropidae) in the bathyal Mediterranean and the adjacent Atlantic. Scientia Marina $62,81-90$

Cuzon G., Cahu C., Aldrin J.F., Messager J.L., Stéphan G. and Mével M. (1980) Starvation effect on metabolism of Penaeus japonicus. Proceedings of the World Mariculture Society 11, 410-423.

Dall W. (1981) Lipid absorption and utilization in the Norwegian lobster, Nephrops norvegicus (L.). Journal of Experimental Marine Biology and Ecology 50, 33-45.

Díaz-Iglesias E., Robles-Murillo A.K., Buesa R.J., Báez-Hidalgo M. and López-Zenteno M. (2011) Bioenergetics of red spiny lobster Panulirus interruptus (Randall, 1840) juveniles fed with mollusc. Aquaculture $318,207-212$.

DuBois M., Gilles K.A., Hamilton J.K., Rebers P.A. and Smith F. (1956) Colorimetric method for determination of sugars and related substances. Analitycal Chemistry 28, 350-356.

Endeco/YSI Incorporated (1992) Operating Manual Type 1125 Pulsed D.O. System, Vol., Marion, MA, USA, pp. 1-40.

Farmer A.S.D. (1975) Synopsis of biological data on the Norway lobster Nephrops norvegicus. FAO Fisheries Synopsis 112, 1-97.

Fowler D.S. and Neil D.M. (1992) Histochemical heterogeneity of fibers in the abdominal superficial flexor muscles of the Norway lobster, Nephrops norvegicus (L.). Journal of Experimental Zoology 264, 406-418.

Gibson R. and Barker P.L. (1979) The decapod hepatopancreas. Oceanography and Marine Biology: an Annual Review 17, 285-346.

Heussner S., Durrieu de Madron X., Calafat A., Canals M., Carbonne J., Delsaut N. and Saragoni G. (2006) Spatial and temporal variability of downward particle fluxes on a continental slope: lessons from an 8 -yr experiment in the Gulf of Lions (NW Mediterranean). Marine Geology 234, 63-92.

Hewitt D.R. and Irving M. (1990) Oxygen consumption and ammonia excretion of the brown tiger prawn Penaeus esculentus fed diets of varying protein content. Comparative Biochemestry and Physiology $96 \mathrm{~A}, 373-378$

Hopkins T.S. (1984) Physics of the sea. In Margalaf R. (ed.) Western Mediterranean. Barcelona: Pergamon Press, pp. 100-125.

Karakoltsidis P.A., Zotos A. and Constantinides S. (1995) Composition of the commercially important Mediterranean finfish, crustaceans, and molluscs. Journal of Food Composition and Analysis 8, 258-273.

Lowry O.H., Rosenberg N.J., Farr A.L. and Randall R.J. (1951) Protein measurement with the Folin phenol reagent. Journal of Biology and Chemistry 193, 265-275.

Main J. and Sangster G.I. (1985) The behaviour of the Norway lobster Nephrops norvegicus (L) during trawling. Scottish Fisheries Research Report 34, 1-23. 
Maynou F. and Sardà F. (1997) Nephrops norvegicus population and morphometrical characteristics in relation to substrate heterogeneity. Fisheries Research 30, 139-149.

Maynou F.X., Sarda F. and Conan G.Y. (1998) Assessment of the spatia structure and biomass evaluation of Nephrops norvegicus (L.) populations in the Northwestern Mediterranean by geostatistics. ICES Journal of Marine Science 55, 102-120.

McLeod L.E., Carter C.G. and Johnston D.J. (2004) Changes in the body composition of adult male southern rock lobster, Jasus edwardsii, during starvation. Journal of Shellfish Research 23, 257-264.

Mente E. (2010) Survival, food consumption and growth of Norway lobster (Nephrops norvegicus) kept in laboratory conditions. Integrative Zoology 5, 256-263.

Mente E., Carter C.G., Barnes R.S. and Karapanagiotidis I.T. (2011) Protein synthesis in wild-caught Norway lobster (Nephrops norvegicus L.). Journal of Experimental Marine Biology and Ecology 409, 208 - 214

Moksness E., Belchier M., Clemmesen C., Cortés D., Doan A., Folkvord A., García A., Geffen A.J., Høie H., Johannessen A., de Pontual H., Rámirez T., Schnack D. and Sveinsbø B. (2000) Manual of tools for recruitment studies. Final Report FAIR- CT96-1371, pp. 1-42.

Neiland K.A. and Scheer B.T. (1953) The influence of fasting and of sinus gland removal on body composition of Hemigrapsus nudus. Part V of the hormonal regulation of metabolism in Crustaceans. Physiology and Comparative Oecology 3, 321-326.

Parslow-Williams P., Goodheir C., Atkinson R.J.A. and Taylor A.C. (2002) Feeding energetics of the Norway lobster, Nephrops norvegicus in the Firth of Clyde, Scotland. Ophelia 56, 101-120.

Parslow-Williams P.J. (1998) Nutritional limitation in populations of the Norway lobster, Nephrops norvegicus (L.) in the Firth of Clyde, Scotland. PhD thesis. University of Glasgow, UK.

Parslow-Williams P.J., Atkinson R.J.A. and Taylor A.C. (2001) Nucleic acids as indicators of nutritional condition in the Norway lobster Nephrops norvegicus. Marine Ecology Progress Series 211, 235-243.

Perera E., Díaz-Iglesias E., Fraga I., Carrillo O. and Galich G.S. (2007) Effect of body weight, temperature and feeding on the metabolic rate in the spiny lobster Panulirus argus (Latreille, 1804). Aquaculture 265, $261-270$.

Prosser C.L. (1973) Oxygen: respiration and metabolism. In Prosser C.l. (ed.) Comparative animal physiology. Philadelphia, PA: W.B. Saunders, pp. 165-211.

Rosa R. and Nunes M.L. (2002) Biochemical changes during the reproductive cycle of the deep-sea decapod Nephrops norvegicus on the south coast of Portugal. Marine Biology 141, 1001-1009.

Rotllant G., Anger K., Durfort M. and Sarda F. (2004) Elemental and biochemical composition of Nephrops norvegicus (Linnaeus 1758) larvae from the Mediterranean and Irish Seas. Helgoland Marine Research 58, 206-210.

Rotllant G., Charmantier-Daures M., Charmantier G., Anger K. and Sarda F. (2001) Effects of diet on Nephrops norvegicus (L.) larval and postlarval development, growth, and elemental composition Journal of Shellfish Research 20, 347-352.

Rotllant G., Ribes E., Company J.B. and Durfort M. (2005) The ovarian maturation cycle of the Norway lobster Nephrops norvegicus (Linnaeus, 1758) (Crustacea, Decapoda) from the western Mediterranean Sea. Invertebrate Reproduction \& Development 48, $161-169$.
Sánchez-Paz A., García-Carreño F., Muhlia-Almazán A., PeregrinoUriarte A.B., Hernández-López J. and Yepiz-Plascencia G. (2006) Usage of energy reserves in crustaceans during starvation: Status and future directions. Insect Biochemistry and Molecular Biology 36, $241-249$.

Sardà F. (1983) Determinación de los estados de intermuda en Nephrops norvegicus (L.), mediante la observación de los pleópodos. Investigación Pesquera 47, 95-112.

Sardà F. (1998a) Nephrops norvegicus comparative biology and fishery in the Mediterranean Sea. Scientia Marina 62 (Supplement 1), 1-143.

Sardà F. (1998b) Symptoms of overexploitation in the stock of the Norway lobster (Nephrops norvegicus) on the 'Serola Bank' (Western Mediterranean Sea off Barcelona). Scientia Marina 62, 295-299.

Sardà F. and Aguzzi J. (2012) A review of burrow counting as an alternative to other typical methods of assessment of Norway lobster populations. Reviews in Fish Biology and Fisheries 22, 409-422.

Sardà F. and Lleonart J. (1993) Evaluation of the Norway lobster (Nephrops norvegicus, L.) resource off the 'Serola' bank off Barcelona (western Mediterranean). Scientia Marina 57, 191-197.

Sardà F. and Valladares F.J. (1990) Gastric evacuation of different foods by Nephrops norvegicus (Crustacea: Decapoda) and estimation of soft tissue ingested, maximum food intake and cannibalism in captivity. Marine Biology 104, 25-30.

Thomas C.W., Crear B.J. and Hart P.R. (2000) The effect of temperature on survival, growth, feeding and metabolic activity of the southern rock lobster, Jasus edwardsii. Aquaculture 185, 73-84.

Tuck I.D., Chapman C.J. and Atkinson R.J.A. (1997) Population Biology of the Norway Lobster, Nephrops norvegicus (L) in the Firth of Clyde, Scotland. 1. Growth and density. ICES Journal of Marine Science 54, 125-135.

Vernet G. and Charmantier-Daurès M. (1994) Mue, autotomie et régéneration. In Grassé P.P. (ed.) Traité de Zoologie. Anatomie, systématique, biologie. Volume VII: Crustacés. Paris: Masson, pp. 107-194.

Vogt G., Storch V., Quinitio E.T. and Pascual F.P. (1985) Midgut gland as monitor organ for the nutritional value of diets in Penaeus monodon (Decapoda). Aquaculture 48, 1-12.

Watts A.J.R. (2012) Nutritional status and trophic dynamics of the norway lobster Nephrops norvegicus (L.). PhD thesis. University of Glasgow, UK.

Wilber D.H. and Wilber P.T.J. (1989) The effects of holding space and diet on the growth of the West Indian spider crab Mithrax spinosissimus (Lamarck). Journal of Experimental Marine Biology and Ecology $131,215-222$

and

Zöllner N. and Kirsch K. (1962) Über die quantitative Bestimmung von Lipoiden (Mikromethode) mittels der vielen natürlichen Lipoiden (allen bekannten Plasmalipoide) gemeinsamen SulfophosphovanillinReaktion. Zeitschrift für die Gesamte Experimentelle Medizin 135 , $545-561$.

\section{Correspondence should be addressed to:}

G. Rotllant

Institut de Ciències del Mar, Consejo Superior de Investigaciones Científicas (ICM-CSIC), Passeig Marítim de la Barceloneta 36-49, 08003 Barcelona, Spain email: guio@icm.csic.es 